Bangladesh J. Sci. Res. 24(2): 107-116, 2011 (December)

\title{
VOLTAMMETRIC STUDIES OF THE INTERACTION OF COPPER(II) WITH MELAMINE IN BRITTON-ROBINSON BUFFER SOLUTION
}

\author{
A. A. Shaikh Badrunnessa, M. S. Rahman, N. A. Pasha and Pradip K. Bakshi* \\ Department of Chemistry, University of Dhaka, Dhaka-1000, Bangladesh
}

\begin{abstract}
The redox behavior of $\mathrm{Cu}(\mathrm{II})$, and its interaction with melamine in BrittonRobinson (BR) buffer solution at different $\mathrm{pH}(0.63-4.06)$ has been studied using cyclic voltammetric method at a glassy carbon electrode (GCE). $\mathrm{Cu}$ (II) exhibits two cathodic peaks of different heights and an anodic peak at lower $\mathrm{pH}$ $(0.63,1.73$ and 3.02). The weak cathodic peak is less prominent at higher $\mathrm{pH}$ and disappeared at $\mathrm{pH} \geq 4.06$. At all studied $\mathrm{pH}, \mathrm{Cu}(\mathrm{II})$ interacts with melamine at different $\mathrm{Cu}(\mathrm{II})$ and melamine molar ratios. However, at $\mathrm{pH} 3.02$ a strong interaction occurs at $1: 2$ molar ratio. This is perhaps the most favorable condition for $\mathrm{Cu}(\mathrm{II})$-melamine interaction.
\end{abstract}

Key words: Britton-Robinson buffer, cyclic voltammetry, copper(II), melamine, glassy carbon electrode

\section{Introduction}

Melamine (2,4,6-triamino-1,3,5-triazine; Mel) (Scheme 1) is a highly symmetrical ligand with six potential $\mathrm{N}$-donor atoms to coordinate to transition metals (Nockemann and Meyer 2004). Despite its apparent promise as a ligand, investigations of melamine in the area of coordination chemistry are remarkably few. The likely reasons are (i) the insolubility of melamine in all common solvents, except hot water, and (ii) the extensive hydrogen bonding tendency of melamine hinders the formation of coordination bond with<smiles>Nc1nc(N)nc(N)n1</smiles><smiles>Nc1nc([NH3+])nc([NH3+])n1</smiles>

Scheme : Structural representation of (1) melamine, and (2) melaminedi-cation

the metal ions. The metal compounds of melamine that was reported till now are exclusively limited to group IB metals $(\mathrm{Cu}, \mathrm{Ag}$, etc.) and categorized as (i) melaminedication (Scheme 2) salts associated with coordination anions (Colombo et al. 1985, Scott et al. 1988), (ii) inorganic salts co-crystallized with melamine (Zheng et al. 1999), and (iii) a few serendipitously formed coordination complexes (Zhu et al. 1999, Goodgame et al. 1999, Meyer et al. 2009, Wiles et al. 2006).

"Corresponding author, E-mail: pkb4321@yahoo.ca. 
There has been a report of a molecular zwitterionic complex $\left[\mathrm{MelH}^{+} \mathrm{HgCl}_{3}{ }^{-}\right](\mathrm{Mel})$ (Nockemann 2002), in which $\mathrm{Hg}(\mathrm{II})$ contacts to one of the three ring $\mathrm{N}$ atoms of melamine. A manganese compound of melamine, $\left(\mathrm{H}_{5} \mathrm{O}_{2}\right)\left(\mathrm{MelH}^{+}\right)_{3}\left[\mathrm{Mn}^{\mathrm{II} / \mathrm{III}}(\mathrm{pydc})_{2}\right]_{2}$ $(\mathrm{OH})\left(\mathrm{pydcH}_{2}\right) \cdot 5 \mathrm{H}_{2} \mathrm{O}$ has been reported recently (Aghabozorg et al. 2009), in which charge is balanced by conversion of one of the water molecules to a hydroxide ion.

Melamine is unlikely to be digested or broken down in human body system although its many molecular characteristics have some similarities with protein molecules. If it is ingested in large amount, it may act as an important precursor of induced stones in the human kidney. Loosely bound metal ions, $\mathrm{Cu}(\mathrm{II}), \mathrm{Co}(\mathrm{II}), \mathrm{Zn}(\mathrm{II})$ etc. that are present in the blood serum in micromolar levels possibly interact with the melamine under in vivo condition and may cause serious renal problems. Thus the investigations of the interaction of melamine with different metal ions are believed to be implicative for better understanding of the melamine stone production mechanism in the human body.

Even though there are some reports on the preparation and characterization of metalmelamine complexes in the literature, the electrochemical investigations of the interaction of melamine with different metal ions are rare. It seems to be an unexplored field of research. Here the redox behavior of $\mathrm{Cu}$ (II) and the interaction of $\mathrm{Cu}$ (II) with melamine in aqueous BR buffer by cyclic voltammetric technique at various $\mathrm{pH}$ and molar ratios are reported. Because of its wide applications in electrocatalysis, sensors, batteries, microelectronics, electroplating and biochemical catalytic systems, copper(II) is targeted first for this study.

\section{Experimental}

\section{Materials}

Analar grade $\mathrm{CuCl}_{2} \cdot 2 \mathrm{H}_{2} \mathrm{O}$ was purchased from E. Merck, India and used without further purification. Analytical grade melamine (BDH, UK) was used in this study. Acetic acid (BDH, UK), phosphoric acid (Merck, Germany), and boric acid (Merck, Germany) were procured. Sodium hydroxide (Merck, Germany) and perchloric acid (BDH, UK) were used as it is available. All aqueous solutions were prepared in doubly distilled water obtained from a Milli-Q water purification system. Experiments were carried out at room temperature.

\section{Equipments}

A cylindrical electrochemical cell consisting of three electrodes system such as glassy carbon as the working electrode, $\mathrm{Ag} / \mathrm{AgCl}$ (satd. $\mathrm{KCl}$ ) as the reference electrode and a platinum wire as the counter electrode was used for cyclic voltammetric measurement. Voltammetry was performed using computerized electrochemical system, Model HQ2040 developed by Advanced Analytics, USA. The $\mathrm{pH}$ of different solution was measured with a $\mathrm{pH}$ meter (Microprocessor $\mathrm{pH}$ meter, model $\mathrm{pH}$ 211, HANNA Instruments). 


\section{Methods}

\section{Preparation of Britton-Robinson (BR) buffer solution}

Britton-Robinson buffer, a universal $\mathrm{pH}$ buffer is performed for the range $\mathrm{pH} 2.0$ to 12.0 . Although the present intention is to investigate the electrochemical behavior of $\mathrm{Cu}(\mathrm{II})$ in whole $\mathrm{pH}$ range it was not possible due to the precipitation of $\mathrm{Cu}(\mathrm{II})$ at higher $\mathrm{pH}$. For the preparation of BR buffer solution, $0.04 \mathrm{M} \mathrm{H}_{3} \mathrm{BO}_{3}, 0.04 \mathrm{M} \mathrm{H}_{3} \mathrm{PO}_{4}$ and $0.04 \mathrm{M} \mathrm{CH}_{3} \mathrm{COOH}$ solutions were prepared, separately. The three solutions were then mixed together with same volume ratio. The desired $\mathrm{pH}$ values were adjusted by adding $0.2 \mathrm{M} \mathrm{NaOH}$ or $\mathrm{HClO}_{4}$ solution. The $\mathrm{pH}$ of the buffer solution was measured using the $\mathrm{pH}$ meter.

\section{Preparation of metal ion and melamine solution}

Metal ion solution of $0.5 \mathrm{mM} \mathrm{Cu}$ (II) was prepared using Britton-Robinson (BR) buffer. For the complexation study, $0.5,1.0,1.5$ and $2.0 \mathrm{mM}$ melamine solutions were also prepared using BR buffer.

\section{Preparation of glassy carbon electrode (GCE) surface}

GCE was polished with fine alumina powder of $0.3 \mu$ or lower size on a wet polishing cloth. For doing so a part of the cloth was made wet with deionized water and alumina powder was sprinkled over it. The GCE was then polished on this surface by pressing softly the electrode against the polishing surface for about 5-10 min. A shiny black mirror like electrode surface was then thoroughly washed with deionized water.

\section{Preparation of cell for voltammetry}

First of all, the cell was filled with desired volume of the experimental solution and the Teflon cap was placed on the cell. The purging glass tube together with electrodes was inserted through the holes. Under computer controlled stirring, experimental solution was deaerated by purging for at least $10 \mathrm{~min}$ with $99.997 \%$ pure nitrogen gas. Thus traces of dissolved oxygen were removed from the solution.

\section{Results and Discussion}

Cyclic voltammetric investigation of $\mathrm{Cu}$ (II) in $\mathrm{BR}$ buffer solution and its interaction with melamine of different concentrations in an identical voltammetric condition has been performed. The results are presented below.

\section{Voltammetric response of $\mathrm{Cu}(\mathrm{II})$ in $\mathrm{BR}$ buffer solution}

Cyclic voltammogram of $0.5 \mathrm{mM} \mathrm{Cu}$ (II) in $\mathrm{BR}$ buffer solution at different $\mathrm{pH}$ has been recorded at GCE within the potential window of +500 to $-500 \mathrm{mV}$. Figure 1 shows a series of cyclic voltammograms of $0.5 \mathrm{mM} \mathrm{Cu}$ (II) in $\mathrm{BR}$ buffer solution with scan rate of 
$100 \mathrm{mV} / \mathrm{s}$ at $0.63,1.73,3.02$ and $4.06 \mathrm{pH}$. In the forward scan two cathodic peaks (Figure 1) at about -37.0 and $-113.8 \mathrm{mV}$ and in the reverse scan an intense anodic peak at about $41.0 \mathrm{mV}$ is observed. The first cathodic peak is assigned for the reduction of $\mathrm{Cu}$ (II) to $\mathrm{Cu}(\mathrm{I})$ and the second peak is for the reduction of $\mathrm{Cu}(\mathrm{I})$ to $\mathrm{Cu}(0)$, while the anodic peak is due to the oxidation of $\mathrm{Cu}(0)$ to $\mathrm{Cu}$ (II) species.

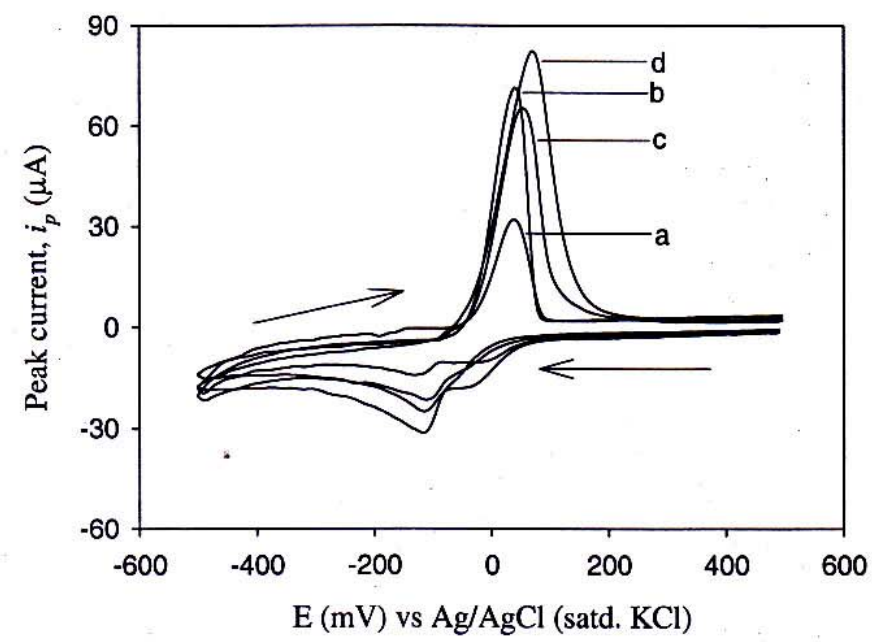

Figure 1. Cyclic voltammograms of $0.5 \mathrm{mM} \mathrm{Cu}$ (II) in $\mathrm{BR}$ buffer at different pH: (a) 0.63 , (b) 1.73, (c) 3.02 and (d) 4.06 at GCE.

With the increase of $\mathrm{pH}$, the current of first cathodic peak gradually decreases and finally disappears at $\mathrm{pH} \geq 4.06$. This fact probably owes much to be the presence of electroactive $\left[\mathrm{Cu}\left(\mathrm{H}_{2} \mathrm{O}\right)_{6}\right]^{2+}$ and $\left[\mathrm{Cu}\left(\mathrm{H}_{2} \mathrm{O}\right)_{6-\mathrm{x}}\right]^{+}$ions in significant amount at low $\mathrm{pH}$ limit while at high $\mathrm{pH}(\sim 4.06),\left[\mathrm{Cu}(\mathrm{OH})\left(\mathrm{H}_{2} \mathrm{O}\right)_{5}\right]^{+}$ion is considered to be the only electroactive species (Anderson and Shain 1976). It is also noticeable that the peak heights of the second cathodic peak and anodic peak increase with increasing $\mathrm{pH}$. Moreover, both of the cathodic and anodic peak potentials are shifted randomly at different $\mathrm{pH}$.

The effect of the scan rate on the electrochemical response of $\mathrm{Cu}(\mathrm{II})$ at $\mathrm{pH} 1.73$ is also examined by recording the cyclic voltammograms of $\mathrm{Cu}$ (II) at scan rates of 25,50 , 75,100 and $125 \mathrm{mVs}^{-1}$ in identical condition. With the increasing of scan rate the cathodic and anodic peak current is increased which is shown in Figure 2. 


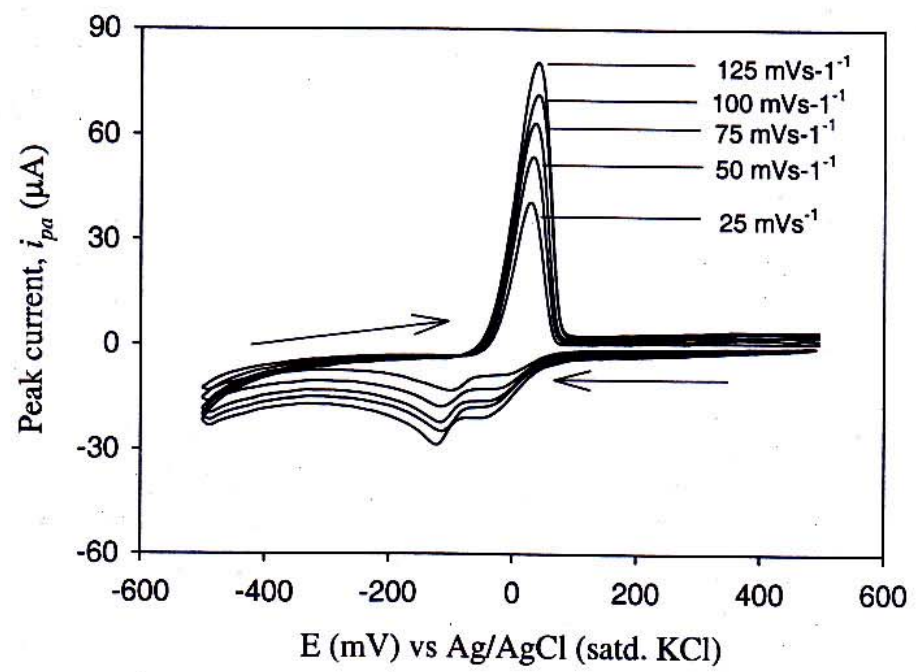

Figure 2. Cyclic voltammograms of $0.5 \mathrm{mM} \mathrm{Cu}(\mathrm{II})$ in BR buffer solution at diferent scan rates of $25,50,75,100$ and $125 \mathrm{mV} / \mathrm{s}$ at $\mathrm{pH} 1.73$.

This observation suggests that the electrode process is diffusion controlled in BR buffer medium. Again the variations of anodic and cathodic peak currents with square root of scan rate are linear (Figure 3 ) that corroborate with Randless-Sevcik equation. Thus the electrode processes are diffusion controlled. The peak potential separation and peak current ratio reveal that the redox process of $\mathrm{Cu}(\mathrm{II}) / \mathrm{Cu}(0)$ is quasireversible, which is also characterized by the shape of the cathodic and anodic peaks (Quentel and Madec 1990).

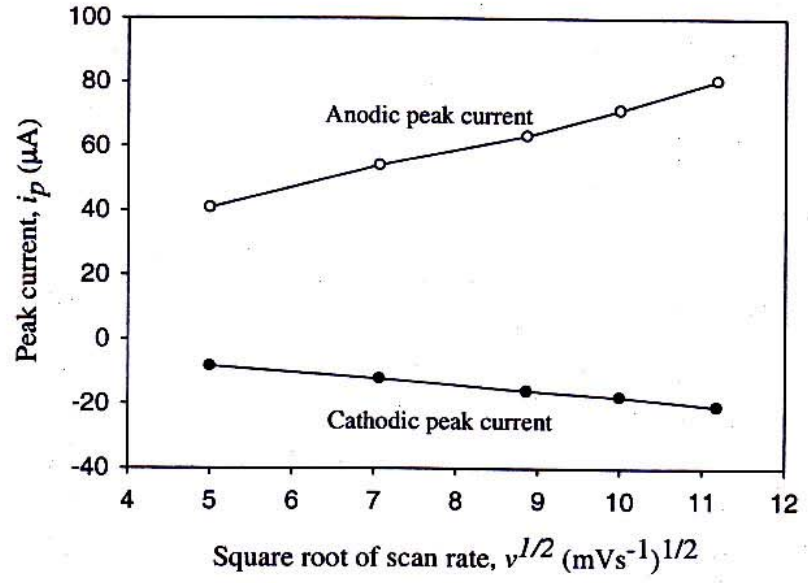

Figure 3. A plot of peak current, $i_{p}(\mu \mathrm{A})$ vs square root of scan rate, $v^{1 / 2}(\mathrm{mV} / \mathrm{s})^{1 / 2}$. 


\section{Voltammetric response of $\mathrm{Cu}(\mathrm{II})$ in presence of melamine in BR buffer solution}

The voltammograms of $\mathrm{Cu}$ (II) in presence of melamine in BR buffer at various $\mathrm{Cu}$ (II) and melamine molar ratio, $1: 1,1: 2,1: 3$ and $1: 4$ have been recorded at $\mathrm{pH} 3.02$ with a glassy carbon electrode (GCE) within the same potential window as it recorded for $\mathrm{Cu}(\mathrm{II})$. Cyclic voltammograms of $\mathrm{Cu}(\mathrm{II})$ in presence of melamine with different molar concentrations of melamine have been recorded (Figure 4). A dramatic change of the voltammograms has been observed. The anodic peak currents in the voltammograms for each molar ratio of $\mathrm{Cu}$ (II) and melamine (Figure 4) are lower than that of solely $\mathrm{Cu}$ (II) while the cathodic peaks disappear completely. The anodic peak potentials are also slightly shifted. Furthermore, the heights of the peaks are apparently erratic with respect to melamine concentration. Since the lowest peak current (Table 1) is found for the voltammogram of $1: 2$ molar ratio of $\mathrm{Cu}$ (II) and melamine, the maximum interaction is indeed, occurred at this molar ratio in this $\mathrm{pH}$ medium.

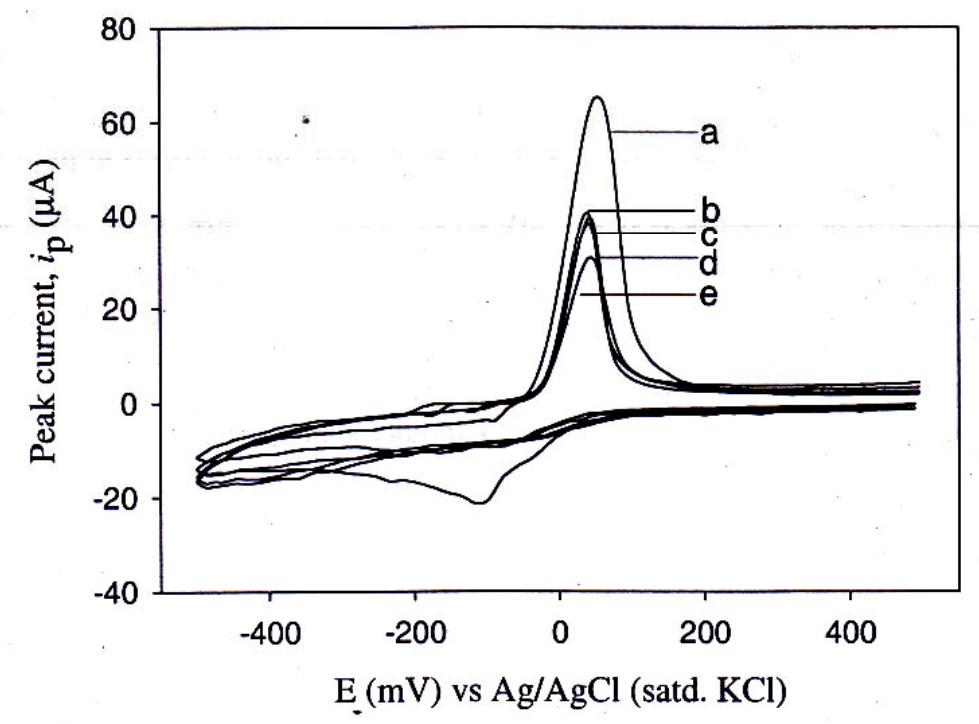

Figure 4. Cyclic voltammograms of (a) $\mathrm{Cu}$ (II), and $\mathrm{Cu}$ (II) in presence of melamine at different ratio (b) $1: 3$, (c) $1: 1$, (d) $1: 4$ and (e) $1: 2$ in BR buffer at pH 3.02.

It may be noted that the voltammogram of melamine in identical condition has been recorded and it exhibits no anodic or cathodic peak at all $\mathrm{pH}$ range within the studied potential window. Figure 5 , shows a comparative $\mathrm{CVs}$ of $\mathrm{Cu}(\mathrm{II})$ and melamine at identical scan rate $(100 \mathrm{mV} / \mathrm{s})$ and concentration $(0.5 \mathrm{mM})$ at GCE. 


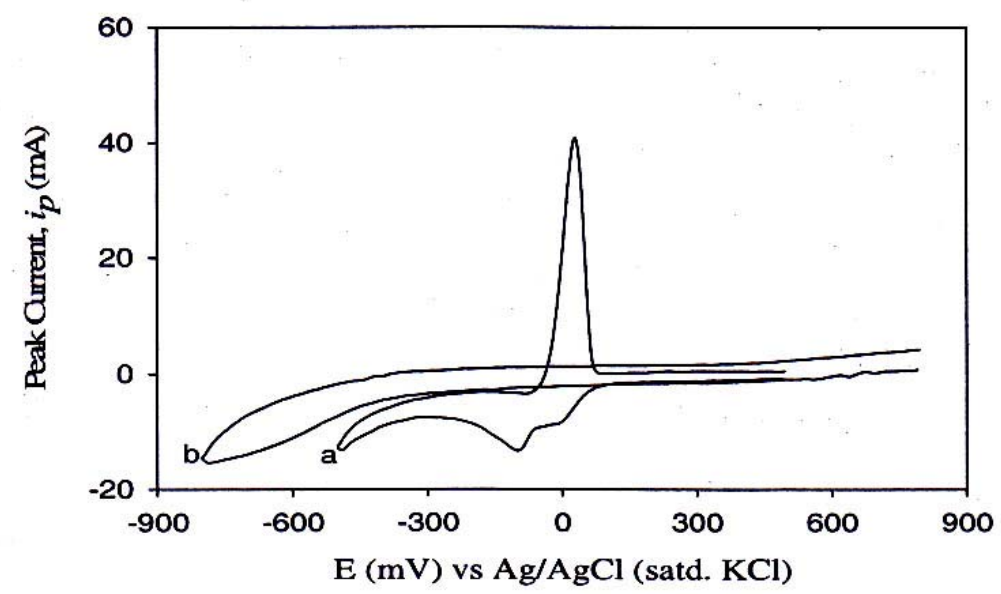

Figure 5. Cyclic voltammograms of (a) $0.5 \mathrm{mM} \mathrm{Cu}$ (II) and (b) $0.5 \mathrm{mM}$ mela mine in BR buffer with scan rate of $100 \mathrm{mV} / \mathrm{s}$ at $\mathrm{GCE}$.

The voltammograms of $\mathrm{Cu}$ (II) at various $\mathrm{Cu}$ (II) and melamine molar ratio, $1: 1$, $1: 2,1: 3$ and $1: 4$ at $\mathrm{pH} 0.63$ have also been examined (Figure 6). At this $\mathrm{pH}$ both the cathodic and anodic peaks are apparent in the voltammograms and their peak currents are relatively lower than that of $\mathrm{Cu}$ (II) alone. The peak potentials are also slightly shifted (Figure 6). Additionally, the heights of the peaks are apparently erratic with melamine concentration. The lowest peak current is again found at $1: 2$ molar ratio of $\mathrm{Cu}$ (II) and melamine and thus the interaction occurs at this molar ratio is maximum.

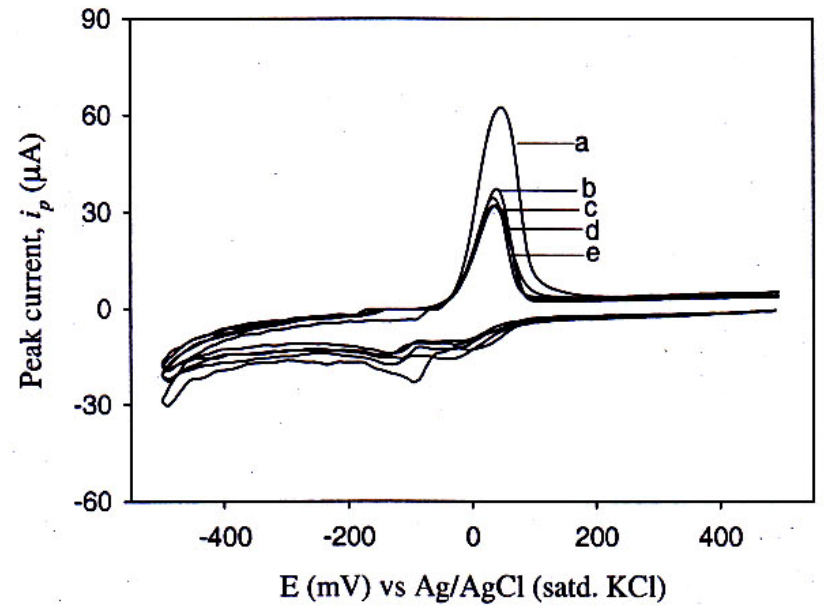

Figure 6. Cyclic voltammograms of (a) $\mathrm{Cu}$ (II), and $\mathrm{Cu}$ (II) in presence of melamine with different molar ratio (b) $1: 3$, (c) $1: 4$, (d) $1: 2$ and (e) $1: 1$ in $B R$ buffer at pH 0.63 . 
In theppresence of melamine, $\mathrm{Cu}$ (II) displays identical electrochemical behavior at $\mathrm{pH}$ 1.73uand 3.02. However, at $\mathrm{pH} 4.06$ the complete disappearance of cathodic peak was nbbserved.IThe common behaviors include (i) the significant dearease of the peak current of $\mathrm{Cu}$ (II), (ii)t thes slight shifting of peak potentials, (iii) the erratic response of peak current with respect to $\mathrm{Cu}(\mathrm{II}) /$ melamine molar ratios, and (iii)t the maximum interaction of $\mathrm{Cu}$ (II) withmmelamine at their $1: 2$ molar ratio. The voltammograms recorded at $\mathrm{pH}$ 11.73and at 4.06 are shown in Figure 7 and Figure 8, respectively.

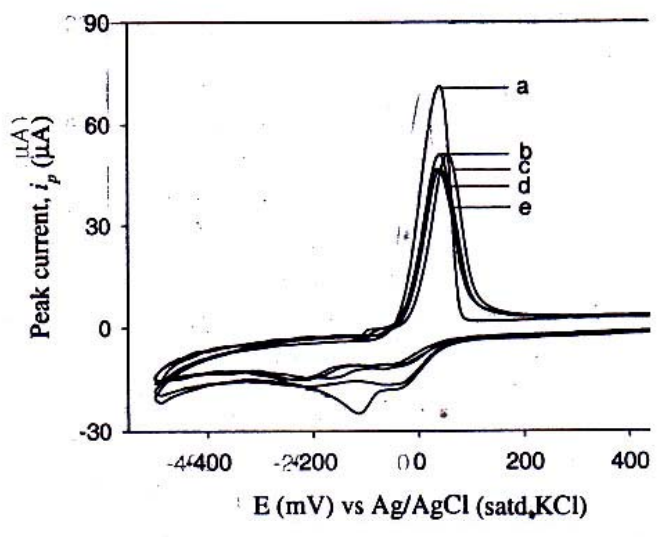

Figure 7. Cyćlic voltammograms of (a) $\mathrm{Cu}(\mathrm{II})$, and $\mathrm{Cu}$ (II) in presence of melamine with different ratio (b) $1: 3$, (c) 1 : 4, (d) $1: 1$ and (e) 1:2 in BR buffer at $\mathrm{pH} / 1.73$.

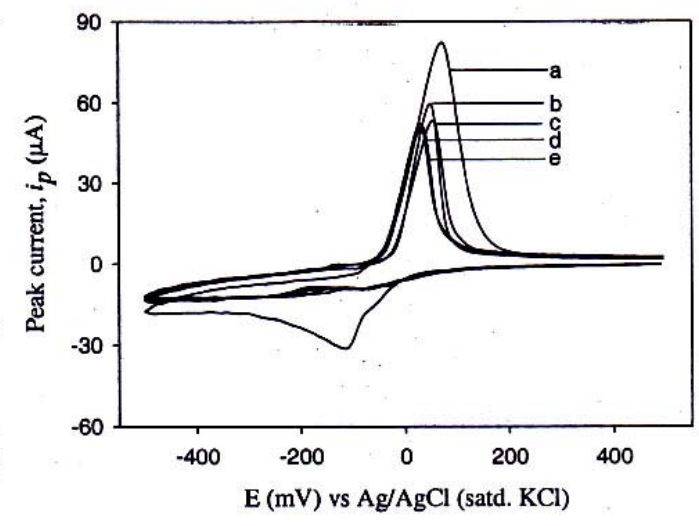

Figure 8. Cyclic voltammograms of (a) $\mathrm{Cu}(\mathrm{II})$, and $\mathrm{Cu}$ (II) in presence of melamine with different ratio (b) $1: 4$, (c) $1: 3$, (d) $1: 1$ and (e) $1: 2$ in $B R$ buffer at pH 4.06.

Table 1IThe data for the voltammograms recorded for $1: 2$ molar ratio of $\mathrm{Cu}(\mathrm{II}) / \mathrm{melamine}$ at different $\mathrm{pH}$ at GCE with scan rate of $100 \mathrm{mV} / \mathrm{s}$.

\begin{tabular}{ccccccc}
\hline $\begin{array}{c}\text { Solution } \\
\mathrm{pH}\end{array}$ & \multicolumn{2}{c}{$\begin{array}{c}\text { Peak current } \\
(\mu \mathrm{A})\end{array}$} & \multicolumn{2}{c}{$\begin{array}{c}\text { Peak potential } \\
(\mathrm{mV})\end{array}$} & $\begin{array}{c}\text { Peak current } \\
\text { ratio }\left(\mathrm{i}_{\mathrm{pa}} / \mathrm{i}_{\mathrm{pc}}\right)\end{array}$ & $\begin{array}{c}\text { Peak potential } \\
\text { separation, } \Delta \mathrm{E}_{\mathrm{p}}\end{array}$ \\
\cline { 2 - 7 } & $-\mathrm{i}_{\mathrm{pc}}$ & $\mathrm{i}_{\mathrm{pa}}$ & $-\mathrm{E}_{\mathrm{pc}}$ & $\mathrm{E}_{\mathrm{pa}}$ & & \\
\hline 0.63 & 14.92 & 31.88 & 137.0 & 33.0 & 2.13 & 170.0 \\
1.73 & 16.95 & 46.55 & 207.0 & 43.0 & 2.74 & 250.0 \\
3.02 & - & 30.66 & - & 43.0 & - & - \\
4.06 & - & 51.32 & - & 33.0 & - & - \\
\hline
\end{tabular}

Epc $=$ Cathodiq peak potential, $\mathrm{Epa}=$ Anodic peak potential, $\mathrm{i}_{\mathrm{pa}}=$ Anodic peak current, $\mathrm{i}_{\mathrm{pc}}=$ Cathödic peak current.

From the above observation it can be concluded that copper(II) interacts with melamine at molar ratio of $1: 2$ in all $\mathrm{pH}$ under study in BR buffer, but the maximum interaction occurs at $\mathrm{pH} 3.02$. The data for the different voltammograms recorded at various $\mathrm{pH}$ is tabulated in Table 1. 


\section{Conclusion}

Voltammetric study of $\mathrm{Cu}(\mathrm{II})$ in $\mathrm{BR}$ buffer exhibits two cathodic peaks of differentt heights and an anodic peak at lower $\mathrm{pH}\left(\mathrm{pH}^{\mathrm{i}} 0.63,1173\right.$ and 3302$\left.\}\right)$.The weaker cathodic peak gradually diminishes with increasing $\mathrm{pH}$ and completely disappears at $\mathrm{pH} 4.06$. However, in the presence of melamine both the cathodic and anodiccpeak currents of $\mathrm{Cu}$ (II) are significantlyy reduced. Thiss observation indicates that the interaction between $\mathrm{Cu}$ (II) and melamine occurs in $\mathrm{BR}$ buffer medium in acidic $\mathrm{pH}^{\prime}$ region. Among the studied $\mathrm{pH}$ region maximum interaction is found at $\mathrm{pH} 3302$; when the molar ratio of $\mathrm{Cu}(\mathrm{III}) /$ melamine is $1: 2$.

\section{Acknowledgement}

Authors are grateful to the Ministry of Science and Information \& Communication Technology, Bangladesh for financialisupport.

\section{References}

Aghabozorg, H., J. A. Gharamaleki, M. M. Olmstead, ZZ. Derikvand and S. Høoshmand. 2009. Hydroxonium hydrate tris(2,4,6-triamino-1,3,5-triazin-1-ium) bis[bis (pyridinee2,6dicarboxylato)(cuprate(II)] pyridine-2,6-dicarboxylic acid hexahydrate. Acta Cryst. E65: m186-m187.

Anderson, J. L. and I. Shain. 1976. Cyclic voltammetric studiess of the $\mathrm{pH}$ dependence of copper(II) reduction in acidlic aqueouss nitrate and perchlorateesolutions. Anall.Chem. 48: 1274-1282.

Colombo, A., L. Menabue, A. Motori, G. C. Pellacani, W.Porzio, E. Sandrolini, and R. D. Willett. 1985. Crystal structure and spectroscopic, magnetic; and electricall properties of a copper(III)dimer, melaminium hexachlorodicuprate, exhibiting a new stacking interaction. Inorg. Chem. 24(19)): 2902905 .

Goodgame, D. M. L., I. Hussain, A. J. P. White, and'D. J. Williamss. 1929. Synthesis and: structure of a copper(II) melamine complex, $\left.\left[\mathrm{Cu}\left(\mathrm{C}_{3} \mathrm{H}_{6} \mathrm{~N}_{6}\right)\right)\left(\mathrm{m}-\mathrm{OCH}_{3}\right)\left(\mathrm{ONO}_{2}\right)\left(\mathrm{HOGH}_{3}\right)\right]_{2}$, with direct Cu-mellamine coordination. J. Chemn Soc. Dalton Transs: 2899-2900.

Meyer, G., M. Sehabi and I. Pantenburg. 2009. Design and construction of coordination polymerss. John Wiley, Inic. pp. 8-10.

Nockemann, P. 2002. Affinity of mercury to nitrogen donor ligands. Ph. D. Dissertation, Universität Zu Köln.

Nockemann, P. and G. Meyer. 2004. Zwitterionic melaminium trichlonomercurate(II),), [ $\left.\mathrm{MelH}^{+} \mathrm{HgCl}_{3}{ }^{-}\right](\mathrm{Mel})$. Z. Anorg. Allg. Chem. 630: 2571-2572.

Quentel, F. and C. Madec. 1990. Woltrammetric study of the copper-1;10-phenanthrolineacomplex. Anal. Chem. Acta. 230: 83-90. 
Scott, B., U. Geiser, R. D. Willett, B. Patyal, C. P. Landee, R. E. Greeney, T. Manfredini, G. C. Pellancani, A. B. Corradi, and L. P. Battaglia. 1988. Structural and magnetic properties of dimorpholinium hexahalodicuprate(II) Salts: $\mathrm{A}$ study of two planar $\mathrm{Cu}_{2} \mathrm{X}_{6}{ }^{2-}$ dimmers. Inorg. Chem. 27: 2454-2460.

Wiles, A. B., D. Bozzuto, C. L. Cahill and R. D. Pike. 2006. Copper (I) and (II) complexes of melamine. Polyhedron. 25: 776-782.

Zheng, Y., L. Jianmin, M. Nishiura, and T. Imamoto. 1999. Melamine-bifunctional metal complex: Self-assembly of high ordered organic-inorganic sandwich layers via hydrogen bonds and pi-pi interactions. Chem. Lett.: 543-544.

Zhu, H., Z. Yu, X. You, H. Hu, and X. Huang. 1999. The crystal and molecular structure of bis(melamine)silver(I) perchlorate, $\mathrm{Ag}\left(\mathrm{C}_{3} \mathrm{H}_{6} \mathrm{~N}_{6}\right)_{2} \mathrm{ClO}_{4}$. J. Chem. Cryst. 29: 239-242.

Manuscript received on 23 June, 2011; revised on 24 November 